\title{
Estrogen- and stress-induced DNA damage in breast cancer and chemoprevention with dietary flavonoid
}

\author{
Michiko T. Yasuda' ${ }^{1}$ Hiroyuki Sakakibara ${ }^{2}$ and Kayoko Shimoi ${ }^{1^{*}}$
}

\begin{abstract}
Breast cancer is one of the most commonly diagnosed female cancers and a leading cause of cancer-related death in women. Multiple factors are responsible for breast cancer and heritable factors have received much attention. DNA damage in breast cancer is induced by prolonged exposure to estrogens, such as 17ß-estradiol, daily social/ psychological stressors, and environmental chemicals such as polycyclic aromatic hydrocarbons (PAHs) and heterocyclic amines (HCAs). DNA damage induced by estrogen and stress is an important factor in the pathogenesis and development of breast cancer and is now recognized as a critical provision for chemoprevention of breast cancer. In this review, we summarize the relationships between estrogen- and stress-induced DNA damage with regard to the pathogenesis and development of breast cancer. We also discuss recent investigations into chemoprevention using dietary flavonoids such as quercetin and isoflavones.
\end{abstract}

Keywords: DNA damage, Breast cancer, Estradiol, Estrogen metabolite, Stress, Stress hormone, Catecholamine, Cortisol Classification: DNA damage

\section{Background}

Breast cancer comprises $18 \%$ of all female cancers and is one of the most common malignant diseases among women [1]. The mortality (rate per 100,000 populations) is reported to be 21.9 in Japan and 89.2 in the United States [1]. The etiology of breast cancer is primarily unknown, but an estimated one quarter of all breast cancers may be caused by heritable factors [2]. These include tumor suppressor genes that encode the DNA repair enzyme breast cancer susceptibility gene $1 / 2$ (BRCA1/2), and the transcription factor p53, which targets stress response genes [3, 4]. In addition, mutations in the gene encoding the protein and lipid phosphatase and tensin homologue (PTEN), are also detected in sporadic breast cancer [5].

In addition to heritable factors, endogenous and exogenous factors levels are also thought to be involved in breast cancer. For example, prolonged exposure to estrogens,

\footnotetext{
*Correspondence: shimoi@u-shizuoka-ken.ac.jp

${ }^{1}$ School of Food and Nutritional Sciences, University of Shizuoka, 52-1 Yada,

Suruga-ku, Shizuoka 422-8526, Japan

Full list of author information is available at the end of the article
}

such as $17 \beta$-estradiol $\left(E_{2}\right)$, unconscious exposure to daily social/psychological stressors and environmental chemicals such as polycyclic aromatic hydrocarbons (PAHs) and heterocyclic amines (HCAs) increase the risk of breast cancer $[6,7]$. DNA damage by various inducers is a wellknown contributor to cancer, including breast cancer. Interestingly, estrogens and their metabolites have been shown to form DNA adducts, which damages DNA and leads to breast cancer [8]. We previously reported that oxidative DNA damage was induced in peripheral blood cells of mice exposed to social isolation stress for 7 days [9]. It was shown that stress hormones, such as glucocorticoid and catecholamines, induced DNA damage [10-12]. Interestingly, treatment with stress hormone blockers was shown to reduce the risk of death from breast cancer [13] And, an in vitro assay showed that stress hormones are potent inducers of migratory activity in breast cancer [14]. Common PAHs include benzo[a]pyrene $(\mathrm{BaP})$ and benz[a]anthracen $(\mathrm{BaA})$, and $\mathrm{BaP}$ is widely distributed in smoked and grilled meat and fish, and $\mathrm{BaA}$ is present in the atmosphere because of incomplete combustion of fossil fuels. These PAHs have been 
shown to initiate cancer (including breast cancer) by inducing DNA damage, such as the formation of DNA adducts, in various tissues [15-18]. Indeed, PAHs have been widely used to experimentally induce breast carcinogenesis [6]. HCAs are a group of mutagenic compounds that are formed during a reaction between amino acids, creatine/creatinine and sugar at high temperatures; therefore, they are found in well-cooked meats [19]. These compounds include 2-amino-1-methyl-6-phenylimidazo [4,5-b] pyridine (PhIP), which is a carcinogen that increases the risk of breast cancer by inducing DNA damage $[20,21]$. The mechanism by which these inducers evoke breast cancer remains unknown, but DNA damage is commonly regarded as an important contributor to breast cancer.

DNA damage occurs often and is usually repaired by intracellular DNA repair mechanisms. If DNA repair mechanisms fail, then cells are programmed to undergo apoptosis. However, if apoptosis is prevented, somatic mutations continue to accumulate, leading to cancer initiation and progression [22, 23]. DNA damage has been shown to trigger various cellular responses such as DNA repair, activation of cell cycle checkpoints, and apoptosis. Activation of checkpoints delays cell cycle progression to facilitate DNA repair or eliminate damaged cells through apoptosis. Defects in these processes contribute to the initiation of cancer, and people with inherited DNA repair deficiency are predisposed to developing cancer [24, 25].

As shown in Fig. 1, PAHs, estrogens, estrogen metabolites, physical/psychological stress induce DNA damage in breast cancer, and the accumulation can lead to an increase in breast cancer risk [26, 27]. For decades, researchers have investigated estrogen-dependent breast cancer and the underlying mechanisms have been elucidated in detail. More recently, attention has focused on how physical/psychological stresses induce DNA damage

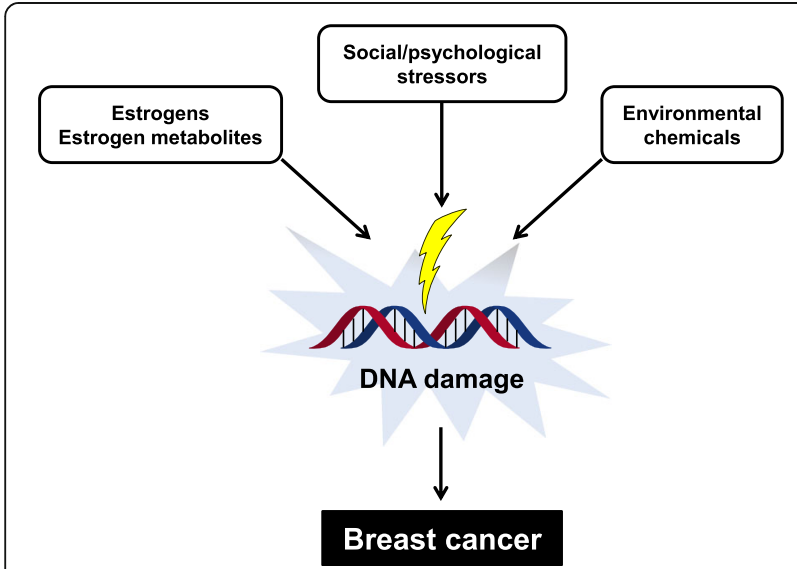

Fig. 1 Various factors can cause DNA damage and increase the risk of breast cancer and recent reports have shown that stress alters DNA repair mechanisms [28, 29].

Stress-mediated DNA damage plays an important role in the pathogenesis and development of breast cancer in addition to estrogen-mediated DNA damage. Studying the relationship between stress-mediated and estrogenmediated DNA damage in relation to breast cancer has been recognized as a critical provision for the chemoprevention of breast cancer. In this review, we aim to consolidate the published findings regarding the relationships between estrogen-mediated and stress-mediated DNA damage in relation to the pathogenesis and development of breast cancer. We also introduce recent findings about the chemoprevention of breast cancer with dietary flavonoids such as quercetin and isoflavones.

\section{Estrogen and breast cancer}

Steroid hormones are important markers of breast cancer status [30, 31], particularly estrogens and their metabolites, which increase the risk of breast cancer [32]. Estrogens are endogenous sex hormones and play important roles in the development and maintenance of reproductive organs and tissue differentiation [33]. High estrogen levels in the breast are associated with an increased cancer risk in women after menopause and elevation of plasma estrogen levels was associated with breast cancer development [30, 34-36]. We previously described that the causes of estrogen-related breast cancer can be divided into two factors [37]. One is the induction of excess proliferation by estrogen receptor (ER) signaling and disrupted DNA repair resulting in the accumulation of DNA damage [38, 39]. The second is DNA damage caused by estrogen-derived metabolites modified by the cytochrome P450 (CYP) 1 family. Metabolism of estrogen is also a key factor in ER-independent carcinogenic effects [40].

The most common estrogen in breast tissue is $E_{2}$, which is mainly produced by ovarian steroidogenesis in premenopausal women. There are two pathways leading to DNA damage by $E_{2}$ : (1) the release of estrogen-DNA adducts from the DNA backbone leaving depurinated sites prone to errors in DNA repair and mutations, and (2) generation of reactive oxygen species (ROS), such as superoxide anion, produced by redox-cycling of catechol estrogens, which cause oxidative DNA damage [40]. The metabolism pathways of estrogen are extremely complex, and involve the production of many metabolites by many enzymes (Fig. 2). Endogenous $\mathrm{E}_{2}$ is hydroxylated to catechol estrogens $2-\mathrm{OHE}_{2}$ and $4-\mathrm{OHE}_{2}$ by CYP1A1 and CYP1B1, respectively [41, 42]. Catechol estrogens are then methylated by catechol-O-methyltransferase $(\mathrm{COMT})$ to 2-methoxy- $\mathrm{E}_{2}$ and 4-methoxy- $\mathrm{E}_{2}$, respectively. 2-methoxy- $\mathrm{E}_{2}$ can inhibit angiogenesis and suppresses tumor growth [43]. One active metabolite is $E_{2}$ - 


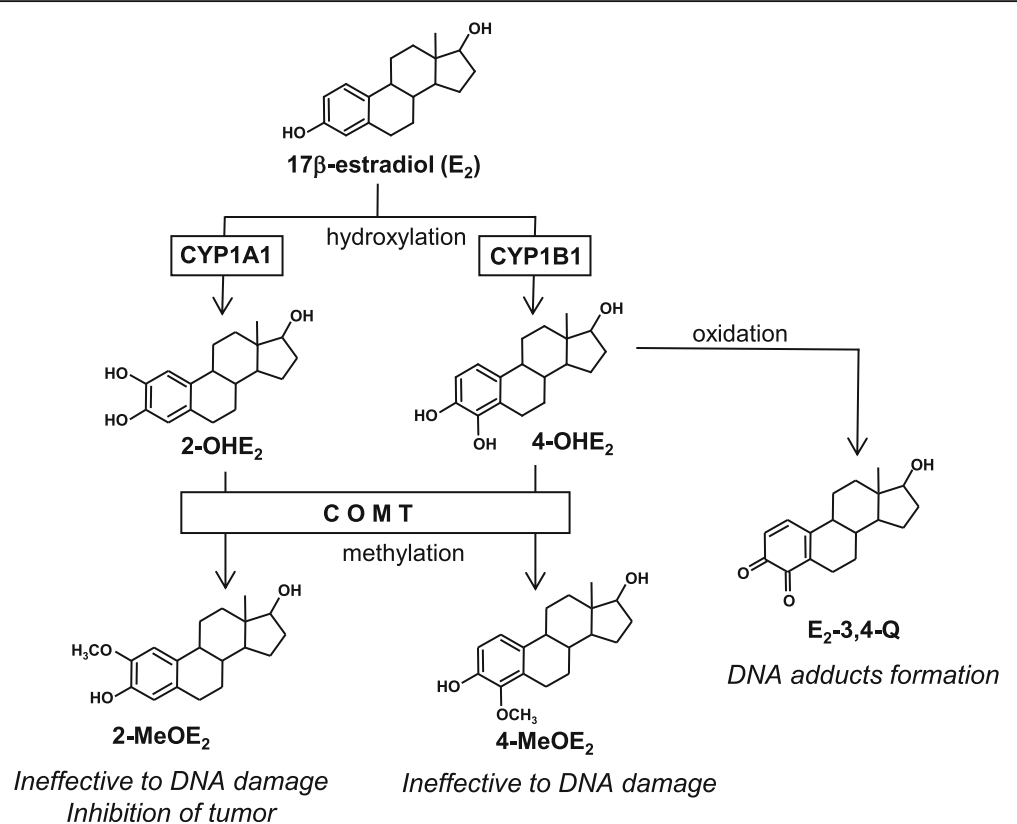

Fig. 2 Schematic representation of typical estrogen metabolism. 17ß-Estradiol $\left(E_{2}\right)$ is most common estrogen in the breast tissue. Endogenous $E_{2}$ is hydroxylated to two types of catechol estrogens, 2-hydroxy- $\mathrm{E}_{2}\left(2-\mathrm{OHE}_{2}\right)$ and 4-hydroxy- $\mathrm{E}_{2}\left(4-\mathrm{OHE}_{2}\right)$, by Cytochrome P450 (CYP) 1A1 and CYP1B1, respectively. These catechol estrogens are further methylated to individual methoxide $E_{2}$, 2-methoxy- $E_{2}\left(2-M_{e O E}\right)$ and 4-methoxy- $E_{2}\left(4-M_{e O E}\right)$, by catechol-O-methyltransferase (COMT). Methoxide $E_{2}$ are basically ineffective compounds to DAN damage, and 2-MeOE ${ }_{2}$ exerts suppressive effects for tumor growth. On the other hand, 4-OHE $\mathrm{E}_{2}$ is oxidized by any oxidative enzyme and/or metal ion, and formed $\mathrm{E}_{2}-3,4-q u i n o n e\left(\mathrm{E}_{2}-3,4-\mathrm{Q}\right)$, which can react with DNA directly

3,4-quinone $\left(E_{2}-3,4-Q\right)$, which is produced by the oxidation of $4-\mathrm{OHE}_{2}$ by any oxidative enzyme or metal ion $[44,45] . E_{2}-3,4-Q$ can react with DNA directly and bind covalently to guanine and/or adenine, destabilizing the glycosylated bond [46-48]. In vitro and in vivo investigations have demonstrated that the unstable adducts of $\mathrm{E}_{2}$ metabolite, 4-OHE $-1-N^{7}$-guanine, and 4-OHE $2-1-N^{3}$ adenine adducts, can be depurinated at the glycoside bond, creating potentially mutagenic abasic sites [35, 49-51]. Wen et al. reported that the accumulation of catechol estrogens in breast tissue in response to increased CYP1B1 and reduced COMT expression can increase breast cancer risk [52]. We previously reported that $4-\mathrm{OHE}_{2}$ and $\mathrm{COMT}$ inhibitors can induce phosphorylated histone $\mathrm{H} 2 \mathrm{AX}$, a marker of DNA damage, in human MCF-7 breast cancer cells [27]. These findings support the significant role of estrogen metabolites in breast cancer development.

The reduction of estrogen quinones to hydroquinones and catechols can produce ROS, such as 8-oxo7, 8-dihydro- 2 '-deoxyguanosine (8-oxo-dG), that cause oxidative DNA damage [53, 54]. Frequent errors in DNA repair can lead to the accumulation of point mutations over a long period of time. Once these mutations cause sufficient DNA damage, the risk of breast cancer is elevated [55].

\section{Stress and breast cancer}

Stress is a state of threatened homeostasis provoked by various stressors. Physiological systems adapt to stress in various ways, including activation of the hypothalamuspituitary-adrenal axis (HPA) as well as the sympatheticadrenal-medullary (SAM) system, which stimulates the production of stress hormones. Prolonged or repeated activation of the HPA and SAM can interfere with their control of other physiological systems, increasing the risk of physical and psychiatric disorders [56, 57]. For several decades, studies have shown that psychological/ physiological stress can contribute to the development and progression of breast cancer [12, 58-61], although the precise mechanisms have not been fully elucidated.

Case studies have shown an increased risk of breast cancer among women with a previous adverse life event or multiple stressful life changes [62-66]. Lillberg et al. investigated the relationship between stressful life events (such as divorce or separation, death of a loved one, loss of a job, increase in amount of work, interpersonal conflict, financial problems) and risk of breast cancer among 10,808 women from a Finnish Twin Cohort. They suggested a role for stressful life events in breast cancer etiology, and one of this mechanisms is associated with various hormonal secretion [67]. Animal experiments have also demonstrated the promotion of breast cancer 
by stress. For example, Hermes et al. and Williams et al. suggested that stress caused by social isolation increased the growth and malignancy of breast cancer tumors in rodents $[68,69]$. Chronic restraint stress has also been shown to increase the rate of primary tumor growth and cause primary tumor to become more metastatic in mouse models of breast cancer [70, 71].

Disturbed circadian rhythm caused by working night shifts has been implicated as a potential risk factor for endocrine-related cancers such as breast cancer [72-74]. Figueiro et al. reported that exposure to light during the night increased cortisol levels in humans [75]. In addition, the international Agency for Research on Cancer has concluded that shift-work is potentially carcinogenic to humans [76].

One possible contributor to stress-induced cancer is the production of stress hormones, such as glucocorticoids (cortisol for humans, corticosterone for rodents) and catecholamines (adrenaline and noradrenaline), which cause damage to DNA [77, 78]. Exposure to physiological/psychological stress induces the production of stress hormones, which bind directly to the cell surface via their specific receptors. Receptor activation induces various cellular responses [79]. Okamoto et al. and Djelic et al. reported that noradrenaline induces DNA breaks and produces ROS [80, 81]. Studies in humans and animals have demonstrated that exposure to stress can contribute to DNA damage [78, 82]. We also demonstrated that stress caused by social isolation induced oxidative DNA damage in mouse peripheral blood cells using a comet assay with formamidopyrimidine DNA glycosylase (FPG). FPG has $N$-glucosidase and AP-lyase activities that are specific for oxidative DNA damage [9]. Flint et al. suggested that cortisol and catecholamines induce DNA damage and interfere with DNA repair, contributing to the transformation of murine 3T3 cells [77]. Hara et al. confirmed that chronic stress causes DNA damage via catecholamine production using animal models and cell lines [11, 83]. They suggested that activation of the $\beta 2$-adrenaline receptor stimulates $\beta$-arrestin- 1 , activating Akt/Mdm2. Mdm2 is an E3-ubiquitin ligase and promotes the degradation of p53. Stimulation of this signaling pathway can cause DNA damage in the frontal cortex of the brain. These results provide evidence that exposure to chronic stress and continuous activation of the sympathetic nervous system can influence genomic integrity in various tissues.

We have previously reported that noradrenaline/adrenaline receptors can induce the activation of several signaling pathways in breast cancer cells to promote invasion [84]. It remains unclear whether this pathway is stimulated by DNA damage caused by catecholamine in our report. However, we have shown that DNA damage is induced by noradrenaline/adrenaline receptors in non- tumorigenic human breast cells [85], suggesting that stress and stress hormones play important roles in the initiation and development of breast cancer via DNA damage. Many studies have demonstrated that stress leads to stress hormone production, which increases the risk of breast cancer by DNA damage. However, further research is required to clarify the mechanisms underlying stress-induced breast cancer.

\section{Estrogen, stress, DNA damage, and cancer}

The initiation and development of breast cancer can be promoted by DNA damage caused by estrogen metabolites and stress. We previously reported the synergistic effects of estrogen metabolites and stress hormones on DNA damage [85]. Combined exposure to 4-OHE2 and noradrenaline at the concentration where $4-\mathrm{OHE}_{2}$ or noradrenaline alone did not cause DNA damage increased DNA damage, including the formation of AP sites and $\gamma-\mathrm{H} 2 \mathrm{AX}$ in human mammary MCF-10A cells $[86,87]$. Based on these findings, we suggest that coexposure to estrogen metabolites and stress represents a novel risk factor in our daily life.

\section{Chemoprevention with dietary flavonoid}

Diets that are rich in fruit and vegetables have been proven to decrease cancer risk $[88,89]$. In addition to beneficial nutrients such as vitamins and minerals, phytochemicals such as flavonoids and other phenolic compounds contribute to these protective effects. Flavonoids are the most common polyphenolic compounds found in plants. We have previously summarized the protective effects of flavonoids against breast cancer; many flavonoids can ameliorate breast cancer by regulating the activity of CYP1 enzymes in animals and humans [37]. Endogenous $\mathrm{E}_{2}$ is hydroxylated to catechol estrogens by CYP1 enzymes; CYP1A1 and CYP1A2 convert $\mathrm{E}_{2}$ to non carcinogenic 2-OHE 2 , and CYP1B1 converts $\mathrm{E}_{2}$ to carcinogenic 4- $\mathrm{OHE}_{2}[41,42]$. Using ethoxyresorufin-Odeethylase, we have shown the effects of 18 flavonoids on CYP1 activity [90] and have summarized these findings in a previous review [37]. The double bond between the $\mathrm{C} 2$ - and $\mathrm{C} 3$-positions of the $\mathrm{C}$-ring means that flavones and flavonols have a tendency to selectively inhibit CYP1B1 activity rather than flavanones. The methoxy substituent on the B-ring also contributes to the strong inhibitory effects on CYP1 activity; acacetin, diosmetin, chrysoeriol, isorhamnetin, tamarixetin, and kaempferide all have strong inhibitory effects on CYP1B1 activity.

The regulation of DNA damage is critical for the chemoprevention of estrogen- and stress-dependent breast cancer. Quercetin, including aglycone and its glycosides, is one of the most well researched dietary flavonoids, and abundant in onions. Their beneficial effects on the prevention of various diseases and bioavailability have 
been well studied [91-95], and we show the schematic representation of typical quercetin metabolism in Fig. 3. We have investigated the effects of quercetin and its principal metabolite quercetin-3-O-glucuronide, on breast cancer and found that these flavonoids can decrease $4-\mathrm{OHE}_{2}$ and noradrenaline-induced DNA damage by preventing the binding of noradrenaline to the adrenaline receptor [85]. Conversely, a high-dose of quercetin is known to induce oxidative DNA damage [96, 97]. Yamashita et al. found that $10-100 \mu \mathrm{M}$ of quercetin induced DNA damage [96] and Murota et al. reported that the major circulating forms of quercetin in human plasma (quercetin sulfate and glucuronide) are present at concentrations of 0.1$1 \mu \mathrm{M}$ [98]. The average dietary intake of quercetin is $16 \mathrm{mg} /$ day, which is a safe concentration regarding DNA damage and could prevent various diseases [96]. We have also shown that noradrenaline induces ROS production, MAPKs activation, pro-tumorigenic gene expression, and invasion in breast cancer MDA-MB-231 cells, but not in non-tumorigenic MCF-10A cells. In addition, $0.1 \mu \mathrm{M}$ of the quercetin metabolite quercetin-
3-O-glucuronide suppresses these responses by influencing the adrenaline receptor [84]. Following onion consumption, $1 \mu \mathrm{M}$ of quercetin-3-O-glucuronide is detected in human plasma (500 g, two onions, containing quercetin glycosides equivalent to $150 \mathrm{mg}$ quercetin aglycone) [98], and to our knowledge, we were the first to demonstrate the inhibitory action of quercetin-3-Oglucuronide at concentrations detectable in human plasma after onion consumption. Noradrenaline stimulates proliferation and promotes migration of MDAMB-231 human breast cancer cells by activating many signaling pathways $[84,99]$. Stress hormone-induced DNA damage may contribute to cancer risk. Thus, blocking interaction of noradrenaline with its receptor using quercetin metabolites may suppress various cancer-causing pathways. Taken together, these findings suggest that dietary intake of quercetin may be a powerful chemopreventive factor for estrogen- and/or stress-related breast cancer.

Phytoestrogens are compounds of plant origin with estrogen-like activity. They act as weak agonists, antagonists, or modulators of human ERs. Isoflavones are

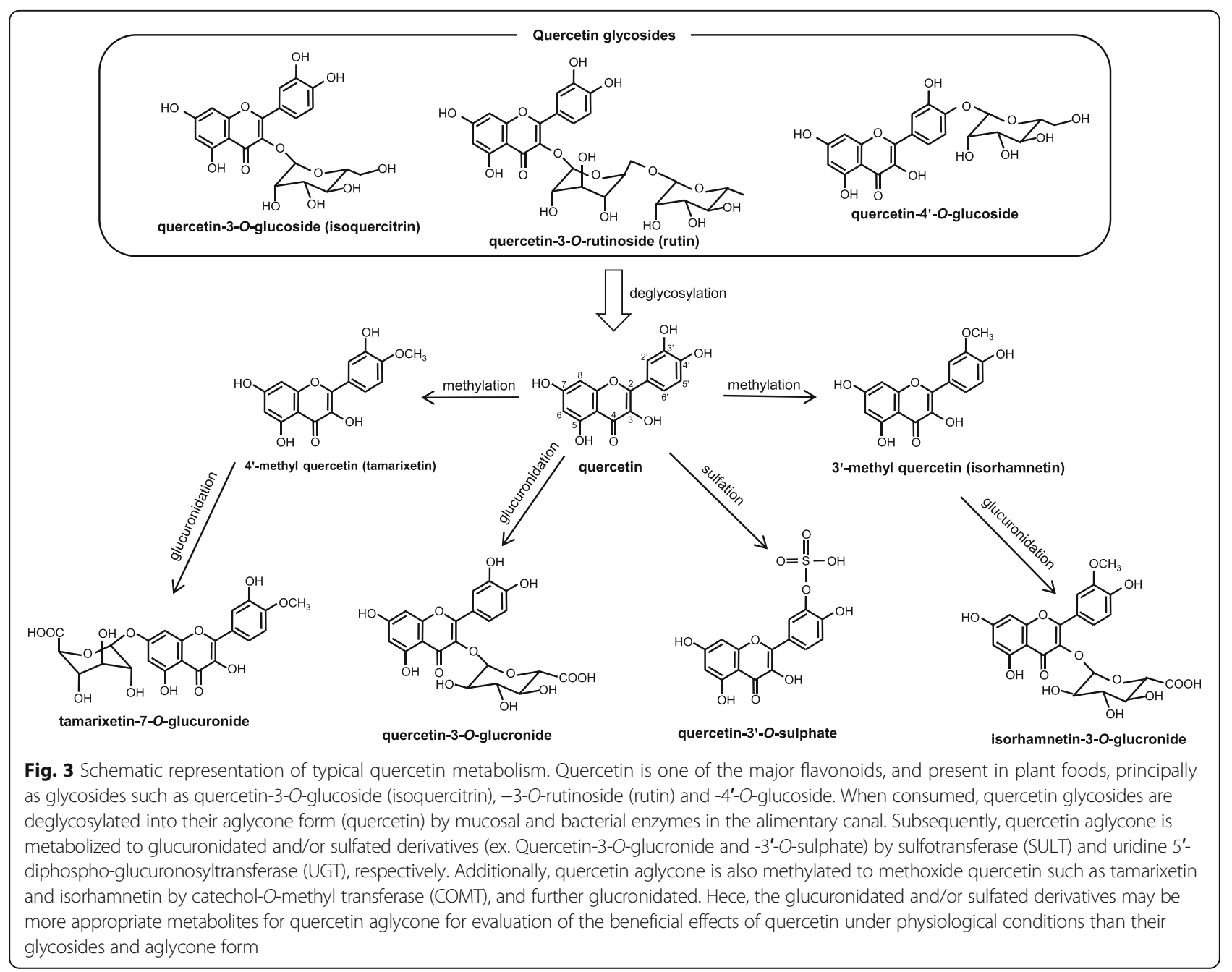




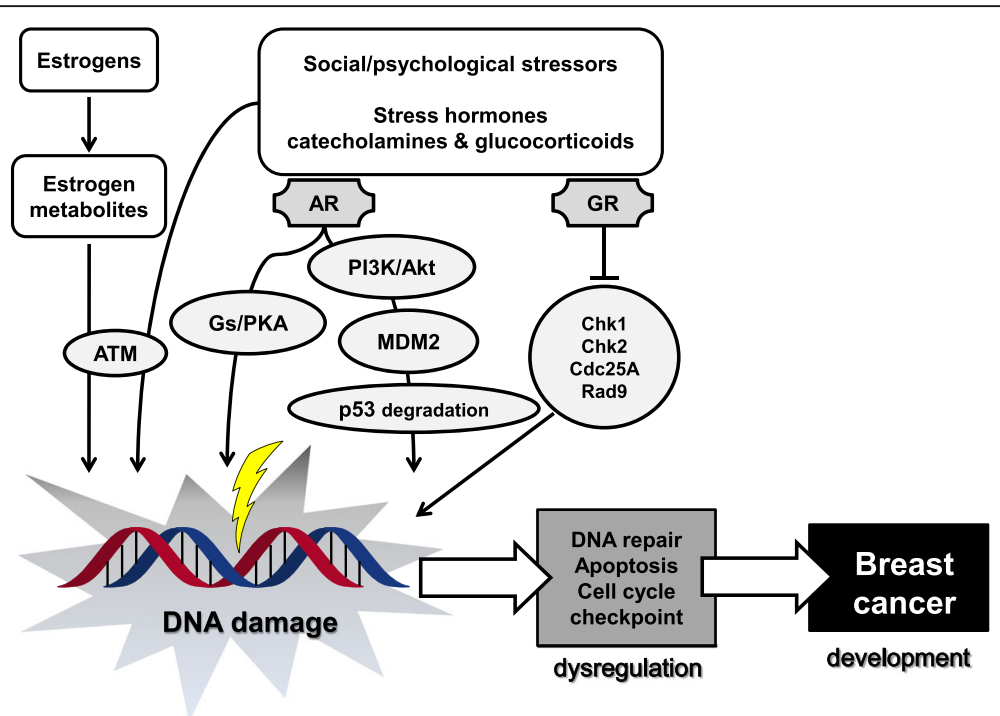

Fig. 4 Summary of DNA damage-induced breast cancer by estrogen and stressors. Stressors induced stress hormones such as catecholamines and glucocorticoids, and these.stress hormones are recognized by each receptor, adrenaline receptor (AR) and glucocorticoid receptor (GR). These receptors activate the downstream pathways. AR stimulate the Gs/protein kinase A (PKA) pathway and phosphoinositide 3-kinase (PI3K)/Akt-mediated murine double minute 2 (MDM2), leading to p53 ubiquitination and degradation [11]. GR regulates the expression of factors critical for DNA damage signaling; Chek1 (Chk1), Chk2, cell division cycle 25 (Cdc25), and Rad9 [77]. Estrogen metabolites and noradrenaline induced DNA damage with Ataxia telangiectasia mutated (ATM) activation $[27,85]$. The activation of these pathways leads to DNA damage, and accumulation of DNA damages result in induction of breast cancer

phytoestrogens and they are found in soybeans. Isoflavones such as genistein and daidzein, and the metabolite equol can bind to ERs [100] and have chemopreventive or the opposite effects on breast cancer [37, 101]. In addition, genistein modulates CYP1 expression and DNA damage in breast cells. Wei et al. suggested that physiological concentrations of genistein $(5 \mu \mathrm{M})$ induce ROS production and stimulate breast cancer cell proliferation by inducing CYP1B1 expression [102]. However, Leung et al. reported that oxidative DNA damage caused by $\mathrm{PAH}$ was inhibited by genistein $(5 \mu \mathrm{M})$ in human breast cells by suppressing CYP1 [103]. These findings showed that genistein can both increase and decrease the risk of breast cancer. Taken together, the roles of isoflavones in breast cancer remain unclear and further research is required to elucidate them.

\section{Conclusion}

Studies have identified various risk factors for breast cancer, and many have supported the hypothesis that estrogen metabolites and stress are key risk factors for breast cancer. Although the mechanisms through which estrogens and stress contribute to breast cancer are complex, DNA damage is possibly involved. As summarized in Fig. 4, a part of these signaling pathways were investigated so far. Estrogen metabolite and stress hormone activates Ataxia telangiectasia mutated (ATM) [27, 85], and stress hormones are recognized by each receptor, followed by activation of the downstream pathways $[11,77]$, resulting in induction of DNA damage. Elucidating the underlying mechanisms in more detail will be of crucial importance for the development of therapeutic or preventative strategies targeting breast cancer.

\section{Acknowledgement}

This review was supported by JSPS KAKENHI grant numbers 25882027 (MY) and $15 \mathrm{H} 02899$ (KS).

\section{Authors' contributions}

KS had the idea for this review, and KS \& MY contributed to the design of the review. MY drafted the manuscript and designed Figs. 1 and 4. HS designed Figs. 2 and 3, and helped to draft the manuscript. KS and HS corrected the manuscript, and MY finally edited it. All authors read and approved the final manuscript, and confirmed they have contributed to the intellectual content of this paper.

\section{Competing interests}

The authors declare that they have no competing interests.

\section{Author details}

${ }^{1}$ School of Food and Nutritional Sciences, University of Shizuoka, 52-1 Yada, Suruga-ku, Shizuoka 422-8526, Japan. ${ }^{2}$ Faculty of Agriculture, University of Miyazaki, 1-1 Gakuen-kibanadai-nishi, Miyazaki 889-2192, Japan.

Received: 14 April 2016 Accepted: 8 December 2016 Published online: 01 February 2017

\section{References}

1. McPherson K, Steel CM, Dixon JM. ABC of breast diseases. Breast cancerepidemiology, risk factors, and genetics. BMJ. 2000;321:624-8.

2. Lichtenstein P, Holm NV, Verkasalo PK, lliadou A, Kaprio J, Koskenvuo M, et al. Environmental and heritable factors in the causation of canceranalyses of cohorts of twins from Sweden, Denmark, and Finland. N Engl J Med. 2000;343:78-85. 
3. Sibille-Hoang C, Froment O, Joos de ter Beerst A, Lepiece V, Huberlant G, Blauwaert $\mathrm{G}$, et al. BRCA1 and BRCA2 mutations in Belgian families with a history of breast and/or ovarian cancer. Eur J Cancer Prev. 1998;7(Suppl 1):S3-5.

4. Lalloo F, Varley J, Ellis D, Moran A, O'Dair L, Pharoah P, et al. Prediction of pathogenic mutations in patients with early-onset breast cancer by family history. Lancet (London, England). 2003:361:1101-2.

5. $\quad$ Eng C. PTEN: one gene, many syndromes. Hum Mutat. 2003;22:183-98.

6. Morris JJ, Seifter E. The role of aromatic hydrocarbons in the genesis of breast cancer. Med Hypotheses. 1992;38:177-84.

7. Rohrmann S, Lukas Jung S-U, Linseisen J, Pfau W. Dietary intake of meat and meat-derived heterocyclic aromatic amines and their correlation with DNA adducts in female breast tissue. Mutagenesis. 2009;24:127-32.

8. Eliassen AH, Hankinson SE. Endogenous hormone levels and risk of breast, endometrial and ovarian cancers: prospective studies. Adv Exp Med Biol. 2008:630:148-65.

9. Nishio $Y$, Nakano $Y$, Deguchi $Y$, Terato $H$, Ide $H$, Ilto C, et al. Social stress induces oxidative DNA damage in mouse peripheral blood cells. Genes Environ. 2007:29:17-22.

10. Flint MS, Bovbjerg DH. DNA damage as a result of psychological stress: implications for breast cancer. Breast Cancer Res. 2012;14:320.

11. Hara MR, Kovacs JJ, Whalen EJ, Rajagopal S, Strachan RT, Grant W, et al. A stress response pathway regulates DNA damage through $\beta 2$ adrenoreceptors and $\beta$-arrestin-1. Nature. 2011:477:349-53.

12. Antonova L, Aronson $K$, Mueller CR. Stress and breast cancer: from epidemiology to molecular biology. Breast Cancer Res. 2011;13:208.

13. Powe DG, Voss MJ, Zänker KS, Habashy HO, Green AR, Ellis IO, et al. Betablocker drug therapy reduces secondary cancer formation in breast cancer and improves cancer specific survival. Oncotarget. 2010;1:628-38.

14. Drell TL, Joseph J, Lang K, Niggemann B, Zaenker KS, Entschladen F. Effects of neurotransmitters on the chemokinesis and chemotaxis of MDA-MB-468 human breast carcinoma cells. Breast Cancer Res Treat. 2003;80:63-70.

15. Wood AW, Huang MT, Chang RL, Newmark HL, Lehr RE, Yagi H, et al. Inhibition of the mutagenicity of bay-region diol epoxides of polycyclic aromatic hydrocarbons by naturally occurring plant phenols: exceptional activity of ellagic acid. Proc Natl Acad Sci U S A. 1982;79:5513-7.

16. Das M, Mukhtar H, Bik DP, Bickers DR. Inhibition of epidermal xenobiotic metabolism in SENCAR mice by naturally occurring plant phenols. Cancer Res. 1987;47:760-6.

17. Springer DL, Mann DB, Dankovic DA, Thomas BL, Wright CW, Mahlum DD. Influences of complex organic mixtures on tumor-initiating activity, DNA binding and adducts of benzo[a]pyrene. Carcinogenesis. 1989;10:131-7.

18. Ralston SL, Coffing SL, Seidel A, Luch A, Platt KL, Baird WM. Stereoselective activation of dibenzo[a, I]pyrene and its trans-11,12-dihydrodiol to fjord region 11,12-diol 13,14-epoxides in a human mammary carcinoma MCF-7 cell-mediated V79 cell mutation assay. Chem Res Toxicol. 1997;10:687-93.

19. Knize MG, Felton JS. Formation and human risk of carcinogenic heterocyclic amines formed from natural precursors in meat. Nutr Rev. 2005;63:158-65.

20. Sinha R, Gustafson DR, Kulldorff M, Wen WQ, Cerhan JR, Zheng W. 2-amino-1methyl-6-phenylimidazo [4,5-b] pyridine, a carcinogen in high-temperaturecooked meat, and breast cancer risk. J Natl Cancer Inst. 2000;92:1352-4.

21. Steck SE, Gaudet MM, Eng SM, Britton JA, Teitelbaum SL, Neugut Al, et al. Cooked meat and risk of breast cancer-lifetime versus recent dietary intake. Epidemiology. 2007;18:373-82.

22. Bartek J, Lukas J. Chk1 and Chk2 kinases in checkpoint control and cancer. Cancer Cell. 2003;3:421-9.

23. Tao W. The mitotic checkpoint in cancer therapy. Cell Cycle Taylor Francis. 2014;4:1495-9.

24. Stuckey AR, Onstad MA. Hereditary breast cancer: an update on risk assessment and genetic testing in 2015. Am J Obstet Gynecol. 2015;213:161-5.

25. Brosens LAA, Offerhaus GJA, Giardiello FM. Hereditary colorectal cancer: genetics and screening. Surg Clin North Am. 2015;95:1067-80.

26. Korsh J, Shen A, Aliano K, Davenport T. Polycyclic aromatic hydrocarbons and breast cancer: a review of the literature. Breast Care (Basel). 2015;10:316-8.

27. Yamazaki S, Sakakibara H, Takemura H, Shimoi K. 4-hydroxyestradiol induces $\mathrm{Y}-\mathrm{H} 2 \mathrm{AX}$ in the presence of an inhibitor of catechol-O-methyltransferase in human breast cancer MCF-7 cells. Genes Environ. 2012;34:129-35.

28. Glaser R, Thorn BE, Tarr KL, Kiecolt-Glaser JK, D'Ambrosio SM. Effects of stress on methyltransferase synthesis: an important DNA repair enzyme. Health Psychol. 1985;4:403-12.
29. Flint MS, Carroll JE, Jenkins FJ, Chambers WH, Han ML, Baum A. Genomic profiling of restraint stress-induced alterations in mouse $T$ lymphocytes. J Neuroimmunol. 2005;167:34-44.

30. Key T, Appleby P, Barnes I, Reeves G. Endogenous sex hormones and breast cancer in postmenopausal women: reanalysis of nine prospective studies. J Natl Cancer Inst. 2002;94:606-16.

31. Sephton SE, Sapolsky RM, Kraemer HC, Spiegel D. Diurnal cortisol rhythm as a predictor of breast cancer survival. J Natl Cancer Inst. 2000;92:994-1000.

32. Eliassen AH, Ziegler RG, Rosner B, Veenstra TD, Roman JM, Xu X, et al. Reproducibility of fifteen urinary estrogens and estrogen metabolites over a 2- to 3-year period in premenopausal women. Cancer Epidemiol Biomarkers Prev. 2009;18:2860-8.

33. Davis JW, Gut M, Lemon HM, Wotiz HH. Studies in steroid metabolism. V. The conversion of testosterone-4-C14 to estrogens by human ovarian tissue. J Biol Chem. 1956:222:487-95.

34. Thomas HV, Reeves GK, Key TJ. Endogenous estrogen and postmenopausal breast cancer: a quantitative review. Cancer Causes Control. 1997:8:922-8.

35. Yager JD, Davidson NE. Estrogen carcinogenesis in breast cancer. N Engl J Med. 2006:354:270-82

36. Kaaks R, Rinaldi S, Key TJ, Berrino F, Peeters PHM, Biessy C, et al Postmenopausal serum androgens, oestrogens and breast cancer risk: the European prospective investigation into cancer and nutrition. Endocr Relat Cancer. 2005;12:1071-82

37. Takemura H, Sakakibara H, Yamazaki S, Shimoi K. Breast cancer and flavonoids - a role in prevention. Curr Pharm Des. 2013;19:6125-32.

38. Halazonetis TD, Gorgoulis VG, Bartek J. An oncogene-induced DNA damage model for cancer development. Science. 2008;319:1352-5.

39. Musgrove EA, Sutherland RL. Biological determinants of endocrine resistance in breast cancer. Nat Rev Cancer. 2009:9:631-43.

40. Santen RJ, Yue W, Wang J-P. Estrogen metabolites and breast cancer. Steroids. 2015;99:61-6.

41. Hayes CL, Spink DC, Spink BC, Cao JQ, Walker NJ, Sutter TR. 17 betaestradiol hydroxylation catalyzed by human cytochrome P450 1B1. Proc Natl Acad Sci U S A. 1996:93:9776-81.

42. Spink DC, Eugster HP, Lincoln DW, Schuetz JD, Schuetz EG, Johnson JA, et al. 17 beta-estradiol hydroxylation catalyzed by human cytochrome P450 1A1: a comparison of the activities induced by 2,3,7,8-tetrachlorodibenzo- $p$ dioxin in MCF-7 cells with those from heterologous expression of the CDNA. Arch Biochem Biophys. 1992;293:342-8.

43. Fotsis T, Zhang Y, Pepper MS, Adlercreutz H, Montesano R, Nawroth PP, et al. The endogenous oestrogen metabolite 2-methoxyoestradiol inhibits angiogenesis and suppresses tumour growth. Nature. 1994;368:237-9.

44. Nelson SD, Mitchell JR, Dybing E, Sasame HA. Cytochrome P-450-mediated oxidation of 2-hydroxyestrogens to reactive intermediates. Biochem Biophys Res Commun. 1976;70:1157-65.

45. Abul-Hajj YJ. Synthesis of 3,4-estrogen-o-quinone. J Steroid Biochem. 1984 21:621-2.

46. Dwivedy I, Devanesan P, Cremonesi P, Rogan E, Cavalieri E. Synthesis and characterization of estrogen 2,3- and 3,4-quinones. Comparison of DNA adducts formed by the quinones versus horseradish peroxidase-activated catechol estrogens. Chem Res Toxicol. 1992;5:828-33.

47. Cavalieri EL, Stack DE, Devanesan PD, Todorovic R, Dwivedy I, Higginbotham S, et al. Molecular origin of cancer: catechol estrogen3,4-quinones as endogenous tumor initiators. Proc Natl Acad Sci U S A. 1997:94:10937-42.

48. Stack DE, Byun J, Gross ML, Rogan EG, Cavalieri EL. Molecular characteristics of catechol estrogen quinones in reactions with deoxyribonucleosides. Chem Res Toxicol. 1996;9:851-9.

49. Hurd C, Khattree N, Alban P, Nag K, Jhanwar SC, Dinda S, et al. Hormonal regulation of the p53 tumor suppressor protein in T47D human breast carcinoma cell line. J Biol Chem. 1995;270:28507-10.

50. Akanni A, Abul-Hajj YJ. Estrogen-nucleic acid adducts: reaction of 3,4estrone-o-quinone radical anion with deoxyribonucleosides. Chem Res Toxicol. 1997:10:760-6.

51. Wang Z, Chandrasena ER, Yuan Y, Peng K, van Breemen RB, Thatcher GRJ, et al. Redox cycling of catechol estrogens generating apurinic/apyrimidinic sites and 8-oxo-deoxyguanosine via reactive oxygen species differentiates equine and human estrogens. Chem Res Toxicol. 2010;23:1365-73.

52. Wen W, Ren Z, Shu XO, Cai Q, Ye C, Gao Y-T, et al. Expression of cytochrome P450 $1 \mathrm{~B} 1$ and catechol-O-methyltransferase in breast tissue and their associations with breast cancer risk. Cancer Epidemiol Biomarkers Prev. 2007;16:917-20. 
53. Liehr JG. Is estradiol a genotoxic mutagenic carcinogen? Endocr Rev. 2000; 21:40-54.

54. Fleck SC, Hildebrand AA, Pfeiffer E, Metzler M. Catechol metabolites of zeranol and 17ß-estradiol: a comparative in vitro study on the induction of oxidative DNA damage and methylation by catechol-O-methyltransferase. Toxicol Lett. 2012;210:9-14.

55. Chakravarti D, Mailander PC, Li KM, Higginbotham S, Zhang HL, Gross ML, et al. Evidence that a burst of DNA depurination in SENCAR mouse skin induces error-prone repair and forms mutations in the $\mathrm{H}$-ras gene. Oncogene. 2001;20:7945-53.

56. McEwen BS. Protective and damaging effects of stress mediators: the good and bad sides of the response to stress. Metabolism. 2002;51:2-4.

57. McEwen BS. Central effects of stress hormones in health and disease: understanding the protective and damaging effects of stress and stress mediators. Eur J Pharmacol. 2008;583:174-85.

58. Antoni MH, Lutgendorf SK, Cole SW, Dhabhar FS, Sephton SE, McDonald PG, et al. The influence of bio-behavioural factors on tumour biology: pathways and mechanisms. Nat Rev Cancer. 2006;6:240-8.

59. Ondicova K, Mravec B. Role of nervous system in cancer aetiopathogenesis. Lancet Oncol. 2010;11:596-601.

60. Lutgendorf SK, Cole S, Costanzo E, Bradley S, Coffin J, Jabbari S, et al. Stressrelated mediators stimulate vascular endothelial growth factor secretion by two ovarian cancer cell lines. Clin Cancer Res. 2003;9:4514-21.

61. Cao L, During MJ. What is the brain-cancer connection? Annu Rev Neurosci. 2012;35:331-45.

62. Cooper CL, Cooper R, Faragher EB. Incidence and perception of psychosocial stress: the relationship with breast cancer. Psychol Med. 1989;19:415-22.

63. Chen CC, David AS, Nunnerley H, Michell M, Dawson JL, Berry H, et al. Adverse life events and breast cancer: case-control study. BMJ. 1995;311: 1527-30.

64. Kruk J, Aboul-Enein HY. Psychological stress and the risk of breast cancer: a case-control study. Cancer Detect Prev. 2004;28:399-408.

65. Kruk J. Self-reported psychological stress and the risk of breast cancer: a case-control study. Stress. 2012;15:162-71.

66. Kocic B, Filipovic S, Vrbic S, Pejcic I, Rancic N, Cvetanovic A, et al. Stressful life events and breast cancer risk: a hospital-based case-control study. J BUON. 2015;20:487-91.

67. Lillberg K, Verkasalo PK, Kaprio J, Teppo L, Helenius H, Koskenvuo M. Stressful life events and risk of breast cancer in 10,808 women: a cohort study. Am J Epidemiol. 2003;157:415-23.

68. Hermes GL, Delgado B, Tretiakova M, Cavigelli SA, Krausz T, Conzen SD, et al. Social isolation dysregulates endocrine and behavioral stress while increasing malignant burden of spontaneous mammary tumors. Proc Natl Acad Sci U S A. 2009:106:22393-8.

69. Williams JB, Pang D, Delgado B, Kocherginsky M, Tretiakova M, Krausz T, et al. A model of gene-environment interaction reveals altered mammary gland gene expression and increased tumor growth following social isolation. Cancer Prev Res (Phila). 2009;2:850-61.

70. Thaker PH, Han LY, Kamat AA, Arevalo JM, Takahashi R, Lu C, et al. Chronic stress promotes tumor growth and angiogenesis in a mouse model of ovarian carcinoma. Nat Med. 2006;12:939-44.

71. Sloan EK, Priceman SJ, Cox BF, Yu S, Pimentel MA, Tangkanangnukul V, et al. The sympathetic nervous system induces a metastatic switch in primary breast cancer. Cancer Res. 2010;70:7042-52.

72. Davis S, Mirick DK, Stevens RG. Night shift work, light at night, and risk of breast cancer. J Natl Cancer Inst. 2001;93:1557-62.

73. Hansen J. Risk of breast cancer after night- and shift work: current evidence and ongoing studies in Denmark. Cancer Causes Control. 2006;17:531-7.

74. Hansen J, Stevens RG. Case-control study of shift-work and breast cancer risk in Danish nurses: impact of shift systems. Eur J Cancer. 2012;48:1722-9.

75. Figueiro MG, Rea MS. The effects of red and blue lights on circadian variations in cortisol, alpha amylase, and melatonin. Int J Endocrinol. 2010; 2010:829351.

76. Straif K, Baan R, Grosse Y, Secretan B, El Ghissassi F, Bouvard V, et al. Carcinogenicity of shift-work, painting, and fire-fighting. Lancet Oncol. 2007;8:1065-6.

77. Flint MS, Baum A, Chambers WH, Jenkins FJ. Induction of DNA damage, alteration of DNA repair and transcriptional activation by stress hormones. Psychoneuroendocrinology. 2007;32:470-9.

78. Gidron Y, Russ K, Tissarchondou H, Warner J. The relation between psychological factors and DNA-damage: a critical review. Biol Psychol. 2006; 72:291-304
79. Dhabhar FS, McEwen BS. Enhancing versus suppressive effects of stress hormones on skin immune function. Proc Natl Acad Sci U S A. 1999;96:1059-64.

80. Okamoto T, Adachi K, Muraishi A, Seki Y, Hidaka T, Toshima H. Induction of DNA breaks in cardiac myoblast cells by norepinephrine. Biochem Mol Biol Int. 1996;38:821-7.

81. Djelic N, Anderson D. The effect of the antioxidant catalase on oestrogens, triiodothyronine, and noradrenaline in the Comet assay. Teratog Carcinog Mutagen. 2003;Suppl 2:69-81. https:/www.ncbinlm.nih.gov/pubmed/14691981.

82. Cwikel JG, Gidron Y, Quastel M. Low-dose environmental radiation, DNA damage, and cancer: the possible contribution of psychological factors. Psychol Health Med. 2010;15:1-16.

83. Hara MR, Sachs BD, Caron MG, Lefkowitz RJ. Pharmacological blockade of a $\beta(2) A R-\beta$-arrestin-1 signaling cascade prevents the accumulation of DNA damage in a behavioral stress model. Cell Cycle. 2013;12:219-24.

84. Yamazaki S, Miyoshi N, Kawabata K, Yasuda M, Shimoi K. Quercetin-3-Oglucuronide inhibits noradrenaline-promoted invasion of MDA-MB-231 human breast cancer cells by blocking $\beta_{2}$-adrenergic signaling. Arch Biochem Biophys. 2014;557:18-27.

85. Yamazaki S, Sakakibara H, Takemura H, Yasuda M, Shimoi K. Quercetin3-O-glucronide inhibits noradrenaline binding to a2-adrenergic receptor, thus suppressing DNA damage induced by treatment with 4hydroxyestradiol and noradrenaline in MCF-10A cells. J Steroid Biochem Mol Biol. 2014;143:122-9.

86. Castagnetta LAM, Granata OM, Traina A, Ravazzolo B, Amoroso M, Miele M, et al. Tissue content of hydroxyestrogens in relation to survival of breast cancer patients. Clin Cancer Res. 2002;8:3146-55.

87. Bierhaus A, Wolf J, Andrassy M, Rohleder N, Humpert PM, Petrov D, et al. A mechanism converting psychosocial stress into mononuclear cell activation. Proc Natl Acad Sci U S A. 2003;100:1920-5.

88. Doll R. An overview of the epidemiological evidence linking diet and cancer. Proc Nutr Soc. 1990:49:119-31.

89. Johnson IT. New approaches to the role of diet in the prevention of cancers of the alimentary tract. Mutat Res. 2004;551:9-28.

90. Takemura H, Itoh T, Yamamoto K, Sakakibara H, Shimoi K. Selective inhibition of methoxyflavonoids on human CYP1B1 activity. Bioorg Med Chem. 2010;18:6310-5.

91. Shimoi K, Yoshizumi K, Kido T, Usui Y, Yumoto T. Absorption and urinary excretion of quercetin, rutin, and alphaG-rutin, a water soluble flavonoid, in rats. J Agric Food Chem. 2003;51:2785-9.

92. Mochizuki M, Kajiya K, Terao J, Kaji K, Kumazawa S, Nakayama T, et al. Effect of quercetin conjugates on vascular permeability and expression of adhesion molecules. Biofactors. 2004;22:201-4.

93. Kawai Y, Nishikawa T, Shiba Y, Saito S, Murota K, Shibata N, et al. Macrophage as a target of quercetin glucuronides in human atherosclerotic arteries: implication in the anti-atherosclerotic mechanism of dietary flavonoids. J Biol Chem. 2008;283:9424-34.

94. Murota K, Shimizu S, Chujo H, Moon JH, Terao J. Efficiency of absorption and metabolic conversion of quercetin and its glucosides in human intestinal cell line Caco-2. Arch Biochem Biophys. 2000;384:391-7.

95. Murota K, Matsuda N, Kashino Y, Fujikura Y, Nakamura T, Kato Y, et al. AlphaOligoglucosylation of a sugar moiety enhances the bioavailability of quercetin glucosides in humans. Arch Biochem Biophys. 2010;501:91-7.

96. Yamashita N, Tanemura H, Kawanishi S. Mechanism of oxidative DNA damage induced by quercetin in the presence of $\mathrm{Cu}(\mathrm{II})$. Mutat Res. 1999; 425:107-15.

97. Das A, Wang JH, Lien EJ. Carcinogenicity, mutagenicity and cancer preventing activities of flavonoids: a structure-system-activity relationship (SSAR) analysis. Prog drug Res Fortschritte der Arzneimittelforschung Progrès des Rech Pharm. 1994;42:133-66.

98. Murota K, Hotta A, Ido H, Kawai Y, Moon J-H, Sekido K, et al. Antioxidant capacity of albumin-bound quercetin metabolites after onion consumption in humans. J Med Invest. 2007;54:370-4.

99. Slotkin TA, Zhang J, Dancel R, Garcia SJ, Willis C, Seidler FJ. Betaadrenoceptor signaling and its control of cell replication in MDA-MB-231 human breast cancer cells. Breast Cancer Res Treat. 2000;60:153-66.

100. Muthyala RS, Ju YH, Sheng S, Williams LD, Doerge DR, Katzenellenbogen BS, et al. Equol, a natural estrogenic metabolite from soy isoflavones: convenient preparation and resolution of R- and S-equols and their differing binding and biological activity through estrogen receptors alpha and beta. Bioorg Med Chem. 2004;12:1559-67. 
101. Messina M, McCaskill-Stevens W, Lampe JW. Addressing the soy and breast cancer relationship: review, commentary, and workshop proceedings. J Natl Cancer Inst. 2006;98:1275-84.

102. Wei YK, Gamra I, Davenport A, Lester R, Zhao L, Wei Y. Genistein induces cytochrome P450 1B1 gene expression and cell proliferation in human breast cancer MCF-7 cells. J Environ Pathol Toxicol Oncol. 2015;34:153-9.

103. Leung HY, Yung LH, Poon CH, Shi G, Lu A-L, Leung LK. Genistein protects against polycyclic aromatic hydrocarbon-induced oxidative DNA damage in non-cancerous breast cells MCF-10A. Br J Nutr. 2009;101:257-62.

Submit your next manuscript to BioMed Central and we will help you at every step:

- We accept pre-submission inquiries

- Our selector tool helps you to find the most relevant journal

- We provide round the clock customer support

- Convenient online submission

- Thorough peer review

- Inclusion in PubMed and all major indexing services

- Maximum visibility for your research

Submit your manuscript at www.biomedcentral.com/submit
Biomed Central 